Abreu \& Stone et. al.

\title{
A Phase 1b/2a Clinical Trial of Dantrolene Sodium in Patients with Wolfram Syndrome
} Damien Abreu $\mathrm{BS}^{1,2 \dagger}$, Stephen I Stone, $\mathrm{MD}^{3 \dagger}$, Toni Pearson $\mathrm{MD}^{4}$, Robert Bucelli MD PhD ${ }^{4}$, Ashley N Simpson RN

$3 \mathrm{BSN}^{5}$, Stacy Hurst RN BSN ${ }^{1}$, Cris M Brown BA ${ }^{1}$, Kelly Kries BA ${ }^{1}$, Hongjie Gu MS ${ }^{6}$, James Hoekel OD ${ }^{7}$, Lawrence

4 Tychsen $\mathrm{MD}^{7}$, Gregory P. Van Stavern $\mathrm{MD}^{7}$, Neil H White $\mathrm{MD}^{3}$, Bess A Marshall $\mathrm{MD}^{3}$, Tamara Hershey $\mathrm{PhD}^{8}$, and 5 Fumihiko Urano $\mathrm{MD} \mathrm{PhD}^{1,9 \pi}$

"These authors contributed equally to this work. "Denotes corresponding author: urano@wustl.edu

${ }^{1}$ Department of Medicine, Division of Endocrinology, Metabolism, and Lipid Research, ${ }^{2}$ Medical Scientist Training

10 Program, ${ }^{3}$ Department of Pediatrics, Division of Endocrinology and Diabetes, ${ }^{4}$ Department of Neurology, ${ }^{5}$ Center

11 for Clinical Studies, ${ }^{6}$ Division of Biostatistics, ${ }^{7}$ Department of Ophthalmology and Visual Sciences, ${ }^{8}$ Departments of

12 Psychiatry and Radiology, ${ }^{9}$ Department of Pathology and Immunology

13 Washington University School of Medicine, St. Louis MO 63110, USA

\section{Abstract}

Background. Wolfram syndrome is a rare endoplasmic reticulum disorder characterized by insulin-dependent

17 diabetes mellitus, optic nerve atrophy, and progressive neurodegeneration. Although there is currently no treatment

18 to delay, halt, or reverse the progression of Wolfram syndrome, preclinical studies in cell and rodent models suggest

19 that therapeutic strategies targeting endoplasmic reticulum calcium homeostasis, including dantrolene sodium, may

20 be beneficial.

21 Methods: Based on the results from preclinical studies on dantrolene sodium and ongoing longitudinal studies, our 22 group put together the first-ever clinical trial in pediatric and adult patients with Wolfram syndrome. An open-label 23 phase $1 \mathrm{~b} / 2 \mathrm{a}$ trial design was chosen. The primary objective of the study was to assess the safety and tolerability of

24 dantrolene sodium in adult and pediatric patients with Wolfram syndrome. Secondary objectives were to evaluate 25 the efficacy of dantrolene sodium on residual pancreatic $\beta$-cell functions, visual acuity, quality of life measures 26 related to vision, and neurological functions.

27 Results: The results indicate that dantrolene sodium is well tolerated by patients with Wolfram syndrome. Although

28 the study was small, a select few patients seemed to have improvements in $\beta$-cell function, which might correlate 29 with a positive trend in other outcome measures, including visual acuity and neurological functions.

30 Conclusion. This study justifies further investigation into using dantrolene sodium and other small molecules 31 targeting the endoplasmic reticulum for the treatment of Wolfram syndrome. 
Abreu \& Stone et. al.

\section{Trial registration}

33 ClinicalTrials.gov Identifier NCT02829268

\section{Conflict of interest statement}

36 F. Urano received research funding from Eli Lilly, Ono Pharmaceuticals, and Amarantus

37 BioScience for the development of MANF-based regenerative therapy for Wolfram syndrome,

38 optic nerve atrophy, and diabetes. F. Urano received chemical compounds from Amylyx

39 Pharmaceuticals, Mitochon Pharmaceuticals, Aetas Pharma, and National Center for Advancing

40 Translational Sciences for the development small molecule-based therapies for ER stress-related

41 disorders, including Wolfram syndrome. F. Urano is an inventor of two patents related to the

42 treatment of Wolfram syndrome, US 9,891,231 B2 SOLUBLE MANF IN PANCREATIC BETA

43 CELL DISORDERS and US 10,441,574, B2 TREATMENT FOR WOLFRAM

44 SYNDROME AND OTHER ER STRESS DISORDERS. F. Urano is a founder of

45 CURE4WOLFRAM, INC.

46

\section{Role of funding source}

48 The funding source had no role in the design of this study, during its execution, analyses,

49 interpretation of the data, or decision to submit results. 
medRxiv preprint doi: https://doi.org/10.1101/2020.10.07.20208694; this version posted October 12, 2020. The copyright holder for this preprint

(which was not certified by peer review) is the author/funder, who has granted medRxiv a license to display the preprint in perpetuity.

It is made available under a CC-BY 4.0 International license .

Abreu \& Stone et. al.

\section{$51 \quad$ Key Points}

52 Question: Is dantrolene sodium safe and effective for the treatment of adult and pediatric

53 patients with Wolfram syndrome?

54 Findings: The results of this open-label clinical trial show that dantrolene sodium is well

55 tolerated by patients with Wolfram syndrome. Although the study was small, a select few

56 patients seemed to have improvements in $\beta$-cell function, which might correlate with a positive

57 trend in other outcome measures, including visual acuity and neurological functions.

58 Meaning: Dantrolene sodium is well tolerated by patients with Wolfram syndrome. Some

59 patients may experience an increase in $\beta$ cell function when taking dantrolene.

60 
medRxiv preprint doi: https://doi.org/10.1101/2020.10.07.20208694; this version posted October 12, 2020. The copyright holder for this preprint (which was not certified by peer review) is the author/funder, who has granted medRxiv a license to display the preprint in perpetuity.

It is made available under a CC-BY 4.0 International license.

Abreu \& Stone et. al.

\section{Abstract}

62 Importance: Wolfram syndrome is a rare endoplasmic reticulum disorder characterized by

63 insulin-dependent diabetes mellitus, optic nerve atrophy, and progressive neurodegeneration.

64 Although there is currently no treatment to delay, halt, or reverse the progression of Wolfram

65 syndrome, preclinical studies in cell and rodent models suggest that targeting endoplasmic

66 reticulum calcium homeostasis, including dantrolene sodium, is an emerging therapeutic

67 strategy.

68 Objective: The primary objective of the study was to assess the safety and tolerability of

69 dantrolene sodium in adult and pediatric subjects with Wolfram syndrome. Secondary objectives

70 were to evaluate the efficacy of dantrolene sodium on residual pancreatic $\beta$-cell functions, visual

71 acuity, quality of life measures related to vision, and neurological functions.

72 Design: Open-label phase $1 \mathrm{~b} / 2 \mathrm{a}$ trial of dantrolene sodium over a 6-month treatment period.

73 Setting: Single site, academic medical center.

74 Participants: Adult and pediatric subjects with a genetically confirmed diagnosis of Wolfram

75 syndrome.

76 Interventions: All subjects received increasing doses of dantrolene sodium.

77 Main Outcomes and Measures: The safety and tolerability of dantrolene sodium administered

78 orally at the upper end of therapeutic dose range for 6 months, and the efficacy of dantrolene

79 sodium on residual pancreatic $\beta$-cell functions using a mixed-meal tolerance test, visual acuity

80 using LogMar scores, quality of life measures related to vision using Visual Functioning

81 Questionnaire - 25, and neurological functions using the Wolfram Unified Rating Scale (WURS)

82 and standard neurological assessments. 
medRxiv preprint doi: https://doi.org/10.1101/2020.10.07.20208694; this version posted October 12, 2020. The copyright holder for this preprint

(which was not certified by peer review) is the author/funder, who has granted medRxiv a license to display the preprint in perpetuity.

It is made available under a CC-BY 4.0 International license .

Abreu \& Stone et. al.

83 Results: The results indicate that dantrolene sodium is well tolerated by subjects with Wolfram

84 syndrome. Although the study was small, a select few subjects seemed to have improvements in

$85 \beta$-cell function, which might be correlated with a positive trend in visual acuity.

86 Conclusions and Relevance: This study justifies further investigation into using dantrolene

87 sodium and other small molecules targeting the endoplasmic reticulum for the treatment of

88 Wolfram syndrome.

89 Trial Registration: Registered with clinicaltrials.gov, NCT02829268,

90 (https://clinicaltrials.gov/ct2/show/NCT02829268?term=NCT02829268\&draw=2\&rank=1) 
medRxiv preprint doi: https://doi.org/10.1101/2020.10.07.20208694; this version posted October 12, 2020. The copyright holder for this preprint (which was not certified by peer review) is the author/funder, who has granted medRxiv a license to display the preprint in perpetuity.

It is made available under a CC-BY 4.0 International license.

Abreu \& Stone et. al.

\section{Introduction}

92 Wolfram syndrome is an ultra-rare, progressive neurodegenerative disorder characterized by

93 juvenile-onset insulin-requiring diabetes mellitus and optic nerve atrophy ${ }^{1,2}$. Other clinical

94 manifestations of Wolfram syndrome include diabetes insipidus, deafness, neurogenic bladder,

95 and ataxia. Most individuals with Wolfram syndrome have a shortened lifespan due to severe

96 neurological disabilities caused by brain stem and cerebellar atrophy ${ }^{3}$. There has yet to be a

97 treatment devised which has been shown to provide a cure or slow the insidious progression of

98 this disease. As a result, patients with Wolfram syndrome are currently only offered therapies

99 aimed at treated each aspect of the disease individually.

100

101 Since the discovery of WFS1 as the causative locus for most cases of Wolfram syndrome, 102 research efforts have sought to understand the underlying etiology of this disorder. Our current 103 understanding is that Wolfram syndrome is a prototype of endoplasmic reticulum (ER) disease in

104 humans ${ }^{4}$. WFS1 is a multi-pass ER transmembrane protein with an established role in the 105 negative regulation of ER stress and the maintenance of cellular calcium homeostasis ${ }^{5,6}$. While 106 the molecular details of WFS1 function require further study, it is clear that pancreatic $\beta$-cells 107 and neurons are particularly affected by, and perhaps especially sensitive to, disease-causing

108 WFS1 genetic variants. Indeed, previous reports from our lab identified calcium dyshomeostasis

109 as a key mechanism underlying pancreatic $\beta$-cell and neuronal cell death in the context of WFS1

110 depletion ${ }^{7-9}$. These pre-clinical studies led to identify dantrolene sodium as a potential

111 therapeutic candidate for restoring ER calcium homeostasis and mitigating the progression of 112 Wolfram syndrome. 
medRxiv preprint doi: https://doi.org/10.1101/2020.10.07.20208694; this version posted October 12, 2020. The copyright holder for this preprint (which was not certified by peer review) is the author/funder, who has granted medRxiv a license to display the preprint in perpetuity.

It is made available under a CC-BY 4.0 International license .

Abreu \& Stone et. al.

114 Dantrolene sodium is a hydantoin derivative skeletal muscle relaxant whose mechanism of action

115 revolves around the inhibition of ryanodine receptors (RyR) on the ER ${ }^{10-12}$. Although the

116 mechanism of action of dantrolene remains unclear, its effects are well-documented. Dantrolene

117 inhibits ER calcium efflux through RyR, thereby reducing cytosolic calcium and preserving ER

118 calcium ${ }^{13}$. The primary indication for dantrolene is in the treatment of malignant hyperthermia,

119 which can be an adverse reaction to general anesthesia and is FDA approved for use in both

120 adults and children. Dantrolene has also been used off-label for the treatments of spasticity

121 disorders and cerebral vasospasm ${ }^{14,15}$. Interestingly, recent studies have proposed a potential role

122 for dantrolene sodium as a treatment for neurodegenerative disorders such as Huntington's

123 disease ${ }^{16}$, spinocerebellar ataxia ${ }^{17,18}$, and Alzheimer's disease ${ }^{19,20}$, where ER calcium may play

124 a pivotal role in disease pathogenesis.

125

126 Murine and induced pluripotent stem cell (iPSC) models of Wolfram syndrome were treated with

127 dantrolene sodium to determine the feasibility of a clinical trial ${ }^{8}$. After receiving promising

128 results from these pre-clinical studies, our group put together the first ever clinical trial in

129 subjects with Wolfram syndrome. Our research team was particularly sensitive to the unique

130 challenges of performing a clinical trial for a disease as rare as Wolfram syndrome ${ }^{21}$. These

131 challenges include the small numbers of subjects available to study and the vast heterogeneity of

132 symptoms exhibited by patients with Wolfram syndrome ${ }^{22}$. Multiple stakeholders were involved

133 in the design of this clinical trial including I-TRAK (a natural history study of neurodegeneration

134 in early Wolfram syndrome, NCT03951298) and various Wolfram syndrome patient/parent

135 advocacy groups as they would be likely sources for recruitment. After these collaborations, an

136 open-label phase $1 \mathrm{~b} / 2 \mathrm{a}$ trial design was chosen. The primary endpoint of the study was to assess 
medRxiv preprint doi: https://doi.org/10.1101/2020.10.07.20208694; this version posted October 12, 2020. The copyright holder for this preprint (which was not certified by peer review) is the author/funder, who has granted medRxiv a license to display the preprint in perpetuity.

It is made available under a CC-BY 4.0 International license.

137 the safety and tolerability of dantrolene sodium in adult and pediatric subjects with Wolfram

138 syndrome. Secondary objectives were also to assess the effect of dantrolene sodium on residual

139 pancreatic $\beta$-cell function, visual acuity, neurological function and quality of life measures. 
medRxiv preprint doi: https://doi.org/10.1101/2020.10.07.20208694; this version posted October 12, 2020. The copyright holder for this preprint (which was not certified by peer review) is the author/funder, who has granted medRxiv a license to display the preprint in perpetuity.

It is made available under a CC-BY 4.0 International license .

Abreu \& Stone et. al.

\section{Results}

\section{Trial population}

142 A total of 22 subjects (6-32 years old) with a genetically confirmed diagnosis of Wolfram

143 syndrome, were screened for enrollment in this study (Figure 1B). Of this group, 21 qualified for

144 baseline laboratory and quality of life assessments in order to begin the run-in regimen of oral

145 dantrolene parallel to ongoing maintenance medications. Two subjects (11\% of qualified

146 population) had to be excluded before the 6-month assessment of study outcome measures on

147 dantrolene treatment due to loss to follow-up or personal reasons. The baseline demographic and

148 clinical characteristics of the 19 subjects that completed the trial are shown in Table 1. Subject-

149 specific WFS1 mutations and clinical data are summarized in Supplementary Table S1. At

150 enrollment $100 \%$ of subjects carried a diagnosis of diabetes mellitus. However, only $63 \%$ of

151 pediatric subjects and $100 \%$ of adult subjects carried a diagnosis of optic atrophy. This pattern is

152 consistent with the documented natural history of Wolfram syndrome, where juvenile-onset

153 diabetes mellitus typically manifests within the first decade, followed by optic atrophy in the

154 second decade of life ${ }^{3,23,24}$.

\section{Safety outcomes}

157 Dantrolene was well-tolerated among pediatric subjects at a final daily dose between $0.5 \mathrm{mg} / \mathrm{kg}$ 158 and $2.0 \mathrm{mg} / \mathrm{kg}$, with a maximun daily dose of $100 \mathrm{mg}$. The mean final daily dose in the pediatric

159 subjects was $1.25 \mathrm{mg} / \mathrm{kg} /$ day (Figure 1C). Adults subjects tolerated dantrolene well between 50

$160 \mathrm{mg}$ to $100 \mathrm{mg}$ daily. 5, 4, and 2 subjects tolerated 50, 75, and $100 \mathrm{mg}$ of dantrolene respectively.

161 This resulted in a mean dose of $68.2 \mathrm{mg}$ daily (Figure 1D). These dosing ranges closely 162 approximated therapeutic ranges for dantrolene when used to treat spasticity ${ }^{25}$. 
medRxiv preprint doi: https://doi.org/10.1101/2020.10.07.20208694; this version posted October 12, 2020. The copyright holder for this preprint (which was not certified by peer review) is the author/funder, who has granted medRxiv a license to display the preprint in perpetuity.

It is made available under a CC-BY 4.0 International license.

Abreu \& Stone et. al.

164 Adverse events were stratified into three categories based on their likelihood of being attributed

165 to the study drug. These categories included adverse events attributed directly to dantrolene,

166 events known to occur commonly in patients with Wolfram syndrome, and non-specific events

167 not easily attributed to dantrolene or Wolfram syndrome. The most common adverse dantrolene

168 related events observed in pediatric and adult subjects were mild fatigue and diarrhea. The most

169 common Wolfram syndrome related events were mild hypoglycemia, and headaches. These

170 symptoms affected at least $25 \%$ of the total study population (Table 2). Hepatoxicity and

171 weakness, the most serious known side effects of dantrolene, were not very prevalent in our

172 study population. Elevated liver enzymes were observed in 2 subjects (11\% of total population)

173 and weakness was self-reported by 4 subjects (21\% of total population). Quantitative

174 assessments of strength prior to and at each subsequent trial visit after dantrolene administration

175 showed no significant loss in grip strength during 6-months of dantrolene treatment

176 (Supplementary Figure 1). No clinically significant changes in laboratory measures or in findings

177 from physical examinations were noted during enrollment in this study. No significant EKG

178 changes were observed in subjects during the run-in period or thereafter. Additionally, no subject

179 discontinued the trial regimen due to adverse effects.

180

181 Secondary outcomes

$182 \quad$-Markers of $\beta$-cell function

183 To assess the effect of dantrolene on glycemia and remaining $\beta$-cell function, HbA1c and 30-

184 minute mixed-meal stimulated C-peptide were monitored at baseline and after 6-months of 185 dantrolene treatment (Figure 1A). Mean HbA1c across all subjects remained stable between 
medRxiv preprint doi: https://doi.org/10.1101/2020.10.07.20208694; this version posted October 12, 2020. The copyright holder for this preprint (which was not certified by peer review) is the author/funder, who has granted medRxiv a license to display the preprint in perpetuity.

It is made available under a CC-BY 4.0 International license .

Abreu \& Stone et. al.

186 dantrolene initiation and after 6-months of treatment $(7.4 \pm 0.2 \%, p$-value 0.63$)$. Subgroup

187 analyses of adult and pediatric subjects also demonstrated no significant change in HbA1c (7.4

$188 \pm 0.2 \%)($ Figure $2 \mathrm{~A})$. Mean fasting C-peptide levels of the total study cohort also remained

189 stable during this period $(0.27 \pm 0.07 \mathrm{ng} / \mathrm{mL}$ at 6 -months of treatment compared to $0.27 \pm 0.06$

$190 \mathrm{ng} / \mathrm{mL}$ at baseline, $p$-value 0.95). At the conclusion of the study, mean stimulated C-peptide

191 levels were not significantly higher compared to the pre-treatment baseline $(0.64 \pm 0.14 \mathrm{ng} / \mathrm{mL}$

192 after 6-months of treatment compared to $0.52 \pm 0.10 \mathrm{ng} / \mathrm{mL}$ at baseline, $p$-value 0.14 ) (Figure

193 2B). Supplementary Figure 2 demonstrates subject specific change in fasting and stimulated C-

194 peptide over the 6-month study period. When looking at all subjects, $\Delta \mathrm{C}$-peptide (the change in

195 C-peptide between 0 and 30 minutes) was not significantly increased. Mean $\Delta \mathrm{C}$-peptide was 0.37

$196 \pm 0.07 \mathrm{ng} / \mathrm{mL}$ after 6 -months of treatment, compared to $0.25 \pm 0.04 \mathrm{ng} / \mathrm{mL}$ at baseline $(p$-value

197 0.18) (Figure 3A and Supplementary Table S2).

198

199 Additional markers of $\beta$-cell function were performed including measuring proinsulin along with

200 C-peptide during the mixed meal tolerance testing. Insulinogenic index ${ }^{26}$ and area under the

201 curve (AUC) C-peptide / AUC Glucose ${ }^{27}$ were calculated for each study subject. No significant

202 differences were found in any of these categories (Supplementary Table S2).

203

204 -Subgroup analyses

205 Additional subgroup analysis was performed in the study population to determine if there was

206 subset of subjects who had the most beneficial response to dantrolene. Our hypothesis was that

207 subjects who possessed the greatest degree of $\beta$ cell function at baseline, would have the greatest

208 glycemic benefit from dantrolene. Therefore, we examined the change in $\Delta \mathrm{C}$-peptide $(\Delta \Delta \mathrm{C}$ - 
medRxiv preprint doi: https://doi.org/10.1101/2020.10.07.20208694; this version posted October 12, 2020. The copyright holder for this preprint (which was not certified by peer review) is the author/funder, who has granted medRxiv a license to display the preprint in perpetuity.

It is made available under a CC-BY 4.0 International license .

Abreu \& Stone et. al.

peptide) over the course of the study to approximate changes in $\beta$ cell responsiveness. $\Delta \Delta \mathrm{C}$ -

210 peptide was calculated by subtracting the $\Delta \mathrm{C}$-peptide at baseline from the $\Delta \mathrm{C}$-peptide at 6-

211 months. In order to test our hypothesis, we divided the subjects based on increasing cutoffs of

$212 \Delta \Delta \mathrm{C}$-peptide $(0.05,0.1$, and $0.2 \mathrm{ng} / \mathrm{mL})$. We noted that 8 subjects had a $\Delta \Delta \mathrm{C}$-peptide $\geq 0.05$

$213 \mathrm{ng} / \mathrm{mL}, 5$ subjects had a $\Delta \Delta \mathrm{C}$-peptide $\geq 0.1 \mathrm{ng} / \mathrm{mL}$, and 4 subjects had a $\Delta \Delta \mathrm{C}$-peptide $\geq 0.2$

$214 \mathrm{ng} / \mathrm{mL}$. The remaining 6 subjects had a $\Delta \Delta \mathrm{C}$-peptide $<0.05 \mathrm{ng} / \mathrm{mL}$ or were missing data

215 necessary for calculation of $\Delta \Delta \mathrm{C}$-peptide (Figure 3A). Review of these data suggested that our

216 hypothesis was correct, as subjects with higher $\Delta \mathrm{C}$-peptide to begin with, tended to have a higher

$217 \Delta \mathrm{C}$-peptide at 6 months and higher slope ( $\Delta \Delta \mathrm{C}$-peptide). To further test this relationship, we

218 performed linear regression analysis demonstrating a statistically significant $\left(\mathrm{R}^{2} 0.439, p\right.$-value

219 0.004) positive relationship between baseline $\Delta \mathrm{C}$-peptide, and ( $\Delta \Delta \mathrm{C}$-peptide) (Figure 3B). A

220 histogram was created to visualize the distribution of $\Delta \Delta \mathrm{C}$-peptide amongst the study subjects

221 (Figure 3C). The $0.05,0.1$, and $0.2 \mathrm{ng} / \mathrm{mL}$ cutoffs were superimposed upon this the linear

222 regression and histograms. Based on previous literature ${ }^{28,29}$, we decided that the cutoff of a

$223 \Delta \Delta \mathrm{C}$-peptide $\geq 0.1 \mathrm{ng} / \mathrm{mL}$ is likely to be of clinical significance, for subjects with Wolfram

224 syndrome. This fit the overall distribution of data, as 5 subjects (subject ID \#4, 8, 10, 17, and

225 22), met this criterion. They represented $26.3 \%$ of the total study population. These subjects

226 included 3 adult and 2 pediatric individuals. The $\Delta \Delta \mathrm{C}$-peptide $\geq 0.1 \mathrm{ng} / \mathrm{mL}$ cutoff is henceforth

227 used to classify subjects as responders versus non-responders.

229 As our hypothesis is that subjects with increased $\beta$ cell function had a more robust response to

230 dantrolene, we set out to determine if any baseline measurement had predictive value. This could

231 help clinicians, caring for patients with Wolfram, determine if dantrolene could be beneficial. 
medRxiv preprint doi: https://doi.org/10.1101/2020.10.07.20208694; this version posted October 12, 2020. The copyright holder for this preprint (which was not certified by peer review) is the author/funder, who has granted medRxiv a license to display the preprint in perpetuity.

It is made available under a CC-BY 4.0 International license .

Abreu \& Stone et. al.

232 Therefore basal, stimulated, and $\Delta \mathrm{C}$-peptide data collected from subjects prior to starting 233 dantrolene were analyzed to determine which of these criteria could best be used. Histograms

234 and receiver-operator-characteristic (ROC) curves were created based on these data. A positive

235 control using $\Delta \Delta \mathrm{C}$-peptide which, by design, demonstrated $100 \%$ sensitivity and specificity

236 using a $\Delta \Delta \mathrm{C}$-peptide value $\geq 0.12 \mathrm{ng} / \mathrm{mL}$ was also created (Supplementary Figure 3D,H).

237 Baseline measurements of $\beta$-cell function had a modest predictive value. Unstimulated (Basal)

238 C-peptide had the highest area under the curve (AUC), demonstrating a peak of $60 \%$ sensitivity,

239 and $100 \%$ specificity when using a cutoff of $0.38 \mathrm{ng} / \mathrm{mL}$. Similarly, stimulated C-peptide

240 demonstrated $60 \%$ sensitivity and $100 \%$ specificity when using a cutoff of $0.725 \mathrm{ng} / \mathrm{mL} . \Delta \mathrm{C}-$

241 peptide had the lowest AUC, demonstrating 40\% sensitivity and 100\% specificity when using a

242 cutoff of $0.44 \mathrm{ng} / \mathrm{mL}$ (Supplementary Figure 3A-C, E-G; Supplementary Table S3)

244 There were no significant differences between responders and non-responders in terms of HbA1c

245 at the beginning $(7.1 \pm 0.2 \%$ and $7.5 \pm 0.2 \%$ respectively, $p$-value 0.49$)$ of the study and after 6-

246 months of treatment $(7.1 \pm 0.3 \%$ and $7.6 \pm 0.3 \%$ respectively, $p$-value 0.42$)$. Prior to treatment

247 with dantrolene, responder subjects had higher fasting C-peptide compared to non-responders

248 (0.47 $\pm 0.17 \mathrm{ng} / \mathrm{dL}$ compared to $0.18 \pm 0.03 \mathrm{ng} / \mathrm{dL}, p$-value 0.03$)$. By design, responder subjects

249 demonstrated statistically significant increases in fasting C-peptide $(0.53 \pm 0.17 \mathrm{ng} / \mathrm{dL}$ to $0.15 \pm$

$250 \quad 0.006 \mathrm{ng} / \mathrm{dL})$, stimulated C-peptide $(1.20 \pm 0.33 \mathrm{ng} / \mathrm{dL}$ to $0.38 \pm 0.05 \mathrm{ng} / \mathrm{dL} p$-value 0.003$)$, and

$251 \Delta$ C-peptide $(0.67 \pm 0.17 \mathrm{ng} / \mathrm{dL}$ to $0.23 \pm 0.02 \mathrm{ng} / \mathrm{dL} p$-value 0.002$)$ after the 6-month treatment

252 period. Similar patterns were seen in between responders and non-responders when measuring

253 proinsulin, insulinogenic index, and AUC C-peptide / AUC Glucose. C-peptide to glucose ratio 
medRxiv preprint doi: https://doi.org/10.1101/2020.10.07.20208694; this version posted October 12, 2020. The copyright holder for this preprint (which was not certified by peer review) is the author/funder, who has granted medRxiv a license to display the preprint in perpetuity.

It is made available under a CC-BY 4.0 International license .

Abreu \& Stone et. al.

254 seemed to be elevated in the pediatric and responder groups compared to adults and non-

255 responders respectively (Supplementary Figure 4, Supplementary Table S4).

256

$257 \quad$-Markers of visual acuity

258 To evaluate the effect of dantrolene treatment on visual acuity and vision-related quality of life,

259 participants underwent ophthalmologic examination at screening, and at baseline, and after 6

260 months of dantrolene treatment. No significant changes in visual acuity were observed across

261 subjects or age groups as a function of dantrolene treatment (Figure 2C, Supplementary Table

262 S2). Of note, subject 12 had a $\operatorname{LogMAR}=3$ throughout the study period, which equates to

263 functional blindness. As a result, subject 12's data was excluded from analysis. Supplementary

264 Figure 5 demonstrates the LogMAR data including subject 12. Subgroup analyses did not

265 identify any significant differences between adult and pediatric subjects or subjects deemed to be

266 non-responders or responders. Correspondingly, subjects reported no significant improvements

267 in vision-related quality of life as measured by the NEIVFQ-25 (Supplementary Table S5).

269 Linear regression analysis was performed comparing $\Delta \Delta \mathrm{C}$-peptide to LogMAR. This resulted in

270 a slight, but statistically significant negative correlation $\left(\mathrm{R}^{2} 0.136, \quad p\right.$-value 0.023$)$

271 (Supplementary Figure 6A).

272

273 -Disease severity and quality of life

274 Overall disease severity was assessed in subjects prior to, and 6-months after starting dantrolene

275 treatment via WURS assessment ${ }^{30}$. There were no differences in total WURS disease severity,

276 or mean physician rated physical exam scores across the 6 months of the study. Subgroup 
medRxiv preprint doi: https://doi.org/10.1101/2020.10.07.20208694; this version posted October 12, 2020. The copyright holder for this preprint (which was not certified by peer review) is the author/funder, who has granted medRxiv a license to display the preprint in perpetuity.

It is made available under a CC-BY 4.0 International license .

Abreu \& Stone et. al.

277 analysis noted that pediatric subjects demonstrated statistically insignificant lower physician

278 rated WURS $(3.1 \pm 1.3$ at baseline and $3.1 \pm 1.2$ after 6-months) ( $p$-value 1.00) than adult

279 subjects $(7.6 \pm 1.8$ at baseline and $8.8 \pm 2.7$ after 6-months) ( $p$-value 0.71$)$ ( $p$-value 0.09 and 0.11

280 at baseline and 6-months respectively when comparing pediatric to adult subjects). Subjects

281 deemed to be responders also demonstrated statistically insignificant lower physician rated

282 WURS scores when comparing baseline (4.2 \pm 1.6$)$ and 6-months $(3.2 \pm 1.2)$ ( $p$-value 0.62).

283 Non-responders saw a statistically insignificant increase in physician rated WURS scores when

284 comparing baseline $(6.3 \pm 1.6)$ to 6 -months of treatment $(7.5 \pm 2.3)(p$-value 0.67$)(p$-value 0.48

285 and 0.28 at baseline and 6-months respectively when comparing non-responder to responder

286 subjects) (Figure 2, and Supplementary Tables S2 and S4). Similarly, pediatric subjects

287 displayed no significant changes in physical or psychosocial health domains as measured by the

288 PedsQL questionnaire between screening and 6 months of dantrolene therapy (Supplementary

289 Table S6) and adult subjects did not show differences in physical or mental health metrics when

290 assessed by the SF-36v (Supplementary Table S7).

292 Similar to the LogMAR data, linear regression analysis was performed correlating $\Delta \Delta \mathrm{C}$-peptide

293 to Total WURS and physician rated WURS. These regression plots appeared to demonstrate a

294 negative correlation, but did not reach statistical significance (R2 0.085, p-value 0.117 and R2

295 0.021, $p$-value 0.444 for total WURS and physician rated WURS respectively) (Supplementary

296 Figure 6 B-C).

297 
medRxiv preprint doi: https://doi.org/10.1101/2020.10.07.20208694; this version posted October 12, 2020. The copyright holder for this preprint (which was not certified by peer review) is the author/funder, who has granted medRxiv a license to display the preprint in perpetuity.

It is made available under a CC-BY 4.0 International license .

Abreu \& Stone et. al.

\section{Discussion}

299 In this study, we evaluate the safety and tolerability of dantrolene sodium as a therapeutic

300 approach for Wolfram syndrome. Our preclinical studies show that dantrolene improves $\beta$-cell

301 and neuronal cell survival in mouse and patient iPSC models of this disease ${ }^{8}$. To translate these

302 findings to humans, we conducted the first clinical trial in pediatric and adult subjects with

303 Wolfram syndrome in a 6-month study of dantrolene sodium (NCT02829268). We identified a

304 tolerable range of oral dantrolene dosing of $0.5 \mathrm{mg} / \mathrm{kg} /$ day to $2 \mathrm{mg} / \mathrm{kg} /$ day for pediatric subjects

305 and $50 \mathrm{mg} /$ day to $100 \mathrm{mg} /$ day for adults. Overall, dantrolene was very well tolerated, and aside

306 from mild fatigue and diarrhea, no clinically significant adverse events were reported.

308 Admittedly, this proof of concept study ran into many of the same issues that plague early

309 clinical trials for rare diseases ${ }^{21}$. As the incidence of Wolfram syndrome is so rare, it is difficult

310 to recruit a large enough sample size in order to detect a statistically significant difference in

311 secondary measures of $\beta$-cell function, visual acuity, or quality of life. In order to aid with

312 recruitment, our study team collaborated with existing natural history studies and patient/parent

313 organizations. Particularly, patient/parent organizations expressed a strong desire for a potential

314 therapeutic option, as there are currently no approved treatments aimed at slowing the

315 progression of Wolfram syndrome. Through the design of the study, potential study subjects

316 lobbied strongly against a blinded or placebo-controlled study design. This helped inform our

317 decision toward an open-label phase 1b/2a design, as a positive outcome would clear a path for

318 more widespread adoption of a drug aimed at slowing the progression of Wolfram syndrome that

319 is at least proven to be safe, if not necessarily effective in all individuals. The final challenge

320 facing this study is the vast clinical heterogeneity seen in the spectrum of individuals with 
medRxiv preprint doi: https://doi.org/10.1101/2020.10.07.20208694; this version posted October 12, 2020. The copyright holder for this preprint (which was not certified by peer review) is the author/funder, who has granted medRxiv a license to display the preprint in perpetuity.

It is made available under a CC-BY 4.0 International license .

Abreu \& Stone et. al.

321 Wolfram syndrome ${ }^{31}$. Independent of age, some individuals are more severely affected or

322 progress more rapidly than others. Our hypothesis is that these differences may be based on the

323 severity of the WFS1 gene variants. For example, individuals with missense mutations, may have

324 a less severe course compared to large deletions or non-sense mutations. This clinically and

325 genetically heterogeneous population makes it more challenging to infer cause and effect

326 relationships when studying a potential drug. As a result, our strategy has been to target the

327 underlying cellular defect (ER calcium depletion) that is unified amongst all patients with

328 Wolfram syndrome ${ }^{32}$.

330 With the above challenges in mind, there remain many shortcomings of this study. As it is an

331 uncontrolled study, certain parameters measured are susceptible to confounding by the placebo

332 effect. Due to the small sample sizes there were no statistically significant differences in $\beta$-cell

333 function or disease severity. For these reasons, this study does not posit that dantrolene improves

$334 \beta$-cell function or disease severity. Instead, it identifies safe doses for treatment of adult and

335 pediatric subjects with Wolfram syndrome, highlights the side effect profile of dantrolene in this

336 population and argues that further investigation of dantrolene, or investigational agents with a

337 similar mechanism of action, are warranted in a randomized, double-blind, placebo-controlled

338 study. With this caveat in mind, this study also suggests that dantrolene requires further

339 investigation in the context of $\beta$-cell function and neurodegeneration.

341 Perhaps the most salient question arising from this study is whether dantrolene improves human

$342 \beta$-cell function in Wolfram syndrome. Mean stimulated C-peptide was not significantly different

343 when looking at all subjects. However, parsing subjects by age reveals that pediatric subjects had 
medRxiv preprint doi: https://doi.org/10.1101/2020.10.07.20208694; this version posted October 12, 2020. The copyright holder for this preprint (which was not certified by peer review) is the author/funder, who has granted medRxiv a license to display the preprint in perpetuity.

It is made available under a CC-BY 4.0 International license .

Abreu \& Stone et. al.

344 a statistically insignificant increase in C-peptide. Subgroup analyses, suggests that subjects with

345 better baseline $\beta$-cell function (earlier on in the progression of the disease and $\beta$-cell loss) may

346 have the most benefit from dantrolene sodium (Figure 3B). Interestingly, linear regression

347 analysis also demonstrated that subjects with the greatest increase in $\beta$-cell function tended to

348 have improved visual acuity and less severe disease (Supplementary Figure 6A). These data

349 suggest that the greatest beneficiaries of dantrolene treatment may be newly diagnosed pediatric

350 subjects who retain a significant degree of $\beta$-cell function. The ROC analysis (Supplementary

351 Figure 3) suggests that having a fasting C-peptide $>0.38 \mathrm{ng} / \mathrm{mL}$, can help predict if a subject will

352 have an greater than $0.1 \mathrm{ng} / \mathrm{mL}$ increase $\Delta$ C-peptide over 6 months of dantrolene treatment.

353 While a controlled human study is required to assess dantrolene's efficacy at improving $\beta$-cell

354 function, pediatric subjects in our study started to exhibit a trend towards higher stimulated C-

355 peptide levels after 6-months of sustained dantrolene treatment. Adult subjects, in contrast, show

356 a negligible increase in mean stimulated C-peptide levels throughout their duration of dantrolene

357 treatment. These data suggest that dantrolene may be more effective in pediatric subjects,

358 possibly because these subjects have a larger surviving subpopulation of functional $\beta$-cells

359 during this initial phase of their disease process. Evidently, adult subjects also secrete very low

360 levels of insulin, but dantrolene did not seem to significantly enhance $\beta$-cell function in this

361 group.

362

363 The significance of these small elevations in C-peptide is quite interesting when comparing

364 Wolfram syndrome to type 1 diabetes. Recently, there has been a growing body of literature

365 suggesting that there is clinical benefit from a very small degree of residual $\beta$-cell function.

366 Oram and colleagues published a population-based study in the United Kingdom, demonstrating 
medRxiv preprint doi: https://doi.org/10.1101/2020.10.07.20208694; this version posted October 12, 2020. The copyright holder for this preprint (which was not certified by peer review) is the author/funder, who has granted medRxiv a license to display the preprint in perpetuity.

It is made available under a CC-BY 4.0 International license.

Abreu \& Stone et. al.

367 that $8 \%$ of subjects had a urinary C-peptide-to-creatinine ratio $\geq 0.2 \mathrm{nmol} / \mathrm{mmol}^{29}$. This study 368 and another follow-up study in 2019 demonstrated that this persistent micro-secretion of C-

369 peptide is associated with fewer complications of diabetes and less hypoglycemia ${ }^{28}$. Contrasting

370 these populations, subjects with Wolfram syndrome tend to have much higher C-peptide

371 compared to type 1 diabetes. Notably the preserved C-peptide group in the 2019 study had a

372 mean stimulated C-peptide of $114 \mathrm{pmol} / \mathrm{L}(0.3443 \mathrm{ng} / \mathrm{mL})$. This is compared to a mean

373 stimulated C-peptide of $0.52 \mathrm{ng} / \mathrm{mL}(205 \mathrm{pmol} / \mathrm{L})$ in our study population with Wolfram

374 syndrome. These data suggest that small, statistically insignificant, increases in C-peptide may

375 be clinically significant. Anecdotally, some of the study investigators noticed that the subject's

376 insulin needs decreased during the study, but this was not systematically evaluated in this study.

377 Additionally, many subjects wearing a continuous glucose monitors noticed more stable

378 glycemic patterns. As a result, we suggest that future studies of dantrolene or similar agents track

379 changes in total daily insulin dose (with percentage basal versus bolus) and analyze continuous

380 glucose monitor tracings (i.e. time-in-range, time-in-hypoglycemia, and standard deviation).

382 Similar to $\beta$-cell function, over 6 months of treatment with dantrolene sodium there were no

383 significant differences in markers of visual acuity. Markers of disease severity including WURS

384 score and other pediatric and adult quality of life measures did not significantly change over 6

385 months of treatment with dantrolene sodium. However, we noted that pediatric subjects tended to

386 have lower physician rated WURS scores compared to their adult counterparts. 
medRxiv preprint doi: https://doi.org/10.1101/2020.10.07.20208694; this version posted October 12, 2020. The copyright holder for this preprint

(which was not certified by peer review) is the author/funder, who has granted medRxiv a license to display the preprint in perpetuity.

It is made available under a CC-BY 4.0 International license .

388 We postulate that efficacy of dantrolene may be linked to the nature of the WFS1 mutations in

389 the individual subjects. Over time, and with further experience with dantrolene, perhaps

390 dantrolene can be part of a personalized medicine approach for patients with Wolfram syndrome.

391

392 In summary, this study suggests that dantrolene sodium is safely tolerated by subjects with

393 Wolfram syndrome. Although the study was small, a select few subjects seemed to have

394 improvements in $\beta$-cell function. Therefore, this study justifies further investigation into using

395 dantrolene sodium and other ER-calcium stabilizers for the treatment of Wolfram syndrome. 
medRxiv preprint doi: https://doi.org/10.1101/2020.10.07.20208694; this version posted October 12, 2020. The copyright holder for this preprint (which was not certified by peer review) is the author/funder, who has granted medRxiv a license to display the preprint in perpetuity.

It is made available under a CC-BY 4.0 International license.

Abreu \& Stone et. al.

\section{Methods}

399 Study approval

400 Subjects, and their parent or legal guardian, as appropriate, provided written, informed consent

401 before participating in this study, which was approved by the Human Research Protection Office

402 at Washington University School of Medicine in St. Louis, MO (IRB ID \#201607006).

403

$404 \quad \underline{\text { Trial participants }}$

405 Subjects who met all of the following criteria were eligible for enrolment:

406 1. A definitive diagnosis of Wolfram syndrome, as determined by the following:

407 a. Documented functionally relevant recessive mutations on both alleles of the WFS1 gene

408 or,

409 b. A dominant mutation on one allele of the WFS1 gene based on historical test results (if 410 available) or from a qualified laboratory at screening.

4112 . The subject is at least 5 years of age (biological age) at the time of written informed 412 consent.

$413 \quad 3 . \quad$ The subject, subject's parent(s), or legally authorized guardian(s) must have voluntarily

414 signed an Institutional Review Board/Independent Ethics Committee-approved informed consent

415 form after all relevant aspects of the study have been explained and discussed with the subject.

416 The guardians' consent and subject's assent, as relevant, must be obtained.

418 Study protocol

419 Dantrolene sodium was dispensed to the study subjects via the Washington University's clinical 420 trials pharmacy. Subjects were instructed to take the dantrolene by mouth. Subjects enrolled in 
medRxiv preprint doi: https://doi.org/10.1101/2020.10.07.20208694; this version posted October 12, 2020. The copyright holder for this preprint (which was not certified by peer review) is the author/funder, who has granted medRxiv a license to display the preprint in perpetuity.

It is made available under a CC-BY 4.0 International license .

Abreu \& Stone et. al.

421 this study underwent a run-in period for dose maximization (Figure 1A). Adult subjects were

422 started on up to $25 \mathrm{mg}$ dantrolene daily for seven days, then doubled in dose on a weekly basis

423 up to a maximum of $200 \mathrm{mg}$ dantrolene daily. Pediatric subjects (< 18 -years old) were started on

424 up to $0.5 \mathrm{mg} / \mathrm{kg}$ dantrolene daily (maximum $25 \mathrm{mg}$ ) for seven days, then doubled in dose on a

425 weekly basis up to a maximum of $2 \mathrm{mg} / \mathrm{kg}$ dantrolene daily (maximum $200 \mathrm{mg}$ ), with no dose

426 change if weight fell within $\pm 3 \%$ of the original dosing weight. Dosing calendars were

427 maintained by the study subjects to ensure adherence to the study drug.

$429 \quad$ Safety assessment and outcomes measures

430 Baseline screening procedures included complete physical exam, standard clinical laboratory

431 tests (serum chemistry, liver function tests, hematology, and urinalysis), and 12-lead ECG.

432 Subjects underwent formal visual acuity testing by the co-authors of the study who are either

433 optometrists or ophthalmologists. At baseline, each subject underwent the Wolfram Unified

434 Rating Scale (WURS) ${ }^{30}$. The 30-minute mixed meal tolerance test was performed to assess

435 base-line $\beta$ cell functions as described before ${ }^{24}$. The mixed meal consisted of $6 \mathrm{ml} / \mathrm{kg}$ (maximum

$436360 \mathrm{ml}$ ) of Boost ${ }^{\circledR}$ (Nestle) consumed over a maximum of 5 minutes. After the overnight

437 fasting, blood for glucose and C-peptide measurement was drawn at time 0 (fasting) and 30

438 minutes after the Boost. If a subject's fasting glucose exceeded $250 \mathrm{mg} / \mathrm{dL}$, the test was not

439 performed, but fasting glucose and C-peptide were obtained. An ECG was performed before and

440 4-hours after the first dose of dantrolene was administered during the run-in period, then again at

441 2-months and 6-months. Best-corrected visual acuity was assessed by Snellen optotype and

442 converted to LogMar score ${ }^{33}$. Vision-related quality of life was assessed in all subjects at

443 screening and after 6 months of dantrolene by the National Eye Institute's 25-item Visual 
medRxiv preprint doi: https://doi.org/10.1101/2020.10.07.20208694; this version posted October 12, 2020. The copyright holder for this preprint (which was not certified by peer review) is the author/funder, who has granted medRxiv a license to display the preprint in perpetuity.

It is made available under a CC-BY 4.0 International license .

Abreu \& Stone et. al.

444 Function Questionnaire (VFQ-25) ${ }^{34}$. Functional activities of daily living were assessed in

445 pediatric subjects by the Pediatric Quality of Life Inventory (PedsQL) (https://www.pedsql.org/)

$446{ }^{35}$, while the SF-36v2 (https://www.optum.com/) was used to measure self-reported functional

447 health and well-being of adults at baseline and after 6-months of dantrolene therapy ${ }^{36}$. If no

448 safety concerns were identified at screening, subjects began the 3-week dose maximization

449 period of dantrolene sodium. All baseline screening procedures were repeated again at 6-months

450 of treatment to ensure subject safety and assess dantrolene tolerability. Grip strength was

451 measured at each visit bilaterally using a digital hand dynamometer (CAMRY). A final safety

452 follow-up visit was conducted at 28 days (+/- 7 days) after the last outcome measure evaluation

453 in order to collect additional information on adverse events, concomitant medications, therapies

454 and procedures. For subjects who discontinued the study prior to the first outcomes measures

455 evaluation, safety follow-up visit was conducted within 28 days (+/- 7 days) after the last

456 administration of dantrolene sodium.

$458 \quad \underline{\text { Statistics }}$

459 Secondary outcome measures (HbA1c, Glucose, C-peptide, Proinsulin, Insulinogenic Index,

460 AUC C-peptide/ AUC Glucose, LogMAR, and WURS) were reported with the mean result \pm the

461 standard error of the mean (SEM). T-tests were performed on these secondary outcome measures

462 when comparing the same group using scipy (https://www.scipy.org) and pandas

463 (https://pandas.pydata.org/index.html) programming libraries. Paired t-tests were used when

464 comparing the same group (all-subjects, adults, pediatrics, non-responders, responders) at 0 and

4656 months. Linear regression analyses (including $\mathrm{R}^{2}$ and $p$-values) were constructed using the 466 ordinary least $\quad$ squares using the statsmodels 
medRxiv preprint doi: https://doi.org/10.1101/2020.10.07.20208694; this version posted October 12, 2020. The copyright holder for this preprint (which was not certified by peer review) is the author/funder, who has granted medRxiv a license to display the preprint in perpetuity. It is made available under a CC-BY 4.0 International license .

Abreu \& Stone et. al.

467 (https://www.statsmodels.org/devel/about.html\#about-statsmodels) programming library.

468 Subjects who dropped out of the study or who did not complete a secondary outcome measure

469 were excluded from the analysis. Independent t-tests were performed when comparing adult to

470 pediatric subjects and non-responders to responder subjects. A p-value $<0.05$ was considered

471 significant for all analyses. Figures were constructed with matplotlib (https://matplotlib.org) and

472 seaborn (https://seaborn.pydata.org) programming libraries or GraphPad Prism 8 software

473 (https://www.graphpad.com/scientific-software/prism/). Receiver-operator-characteristic (ROC)

474 curves and calculations were constructed using GraphPad Prism 8 software. 
medRxiv preprint doi: https://doi.org/10.1101/2020.10.07.20208694; this version posted October 12, 2020. The copyright holder for this preprint (which was not certified by peer review) is the author/funder, who has granted medRxiv a license to display the preprint in perpetuity. It is made available under a CC-BY 4.0 International license.

Abreu \& Stone et. al.

\section{Author contributions}

476 FU designed the study. BAM, NHW, TP, RB, and TH advised on the design of the study. ANS

477 recruited participants and ANS and SH managed the study. TP, RB, JH, LT, SIS, BAM, NHW,

478 and FU examined subjects. SH, CMB, and KK collected the data. CM, DA, SIS, TH, and FU

479 analyzed the data. HG and TH advised on the statistical analysis. DA and SIS wrote the first

480 draft of the manuscript and all the authors revised it critically and approved the final version. DA

481 and SIS are co-first authors. 
medRxiv preprint doi: https://doi.org/10.1101/2020.10.07.20208694; this version posted October 12, 2020. The copyright holder for this preprint (which was not certified by peer review) is the author/funder, who has granted medRxiv a license to display the preprint in perpetuity.

It is made available under a CC-BY 4.0 International license .

Abreu \& Stone et. al.

\section{Acknowledgements}

483 This work was partly supported by the grants from the National Institutes of Health 484 (NIH)/NIDDK (DK112921, DK113487, DK020579), NIH/ National Center for Advancing 485 Translational Sciences (NCATS) (TR002065, TR000448) and philanthropic supports from the 486 Silberman Fund, the Ellie White Foundation for the Rare Genetic Disorders, the Snow

487 Foundation, the Unravel Wolfram Syndrome Fund, the Stowe Fund, the Eye Hope Foundation, 488 and the Feiock Fund to F. Urano. Research reported in this publication was also supported by the 489 Washington University Institute of Clinical and Translational Sciences grant UL1TR002345

490 from the NIH/NCATS. The content is solely the responsibility of the authors and does not 491 necessarily represent the official view of the NIH. The authors thank all the members of the

492 Washington University Wolfram Syndrome Study and Research Clinic for their support 493 (https://wolframsyndrome.dom.wustl.edu) and all the participants in the Wolfram syndrome 494 International Registry and Clinical Study, Research Clinic, and Clinical Trials for their time and 495 efforts. D. Abreu was supported by the NIH training grant (F30DK111070). 
medRxiv preprint doi: https://doi.org/10.1101/2020.10.07.20208694; this version posted October 12, 2020. The copyright holder for this preprint (which was not certified by peer review) is the author/funder, who has granted medRxiv a license to display the preprint in perpetuity.

It is made available under a CC-BY 4.0 International license.

Abreu \& Stone et. al.

\section{References}

497 1. Inoue $\mathrm{H}$, Tanizawa $\mathrm{Y}$, Wasson $\mathrm{J}$, et al. A gene encoding a transmembrane protein is 498 mutated in patients with diabetes mellitus and optic atrophy (Wolfram syndrome). Nat

$499 \quad$ Genet. 1998;20(2):143-148.

$500 \quad 2 . \quad$ Urano F. Wolfram Syndrome: Diagnosis, Management, and Treatment. Current diabetes $501 \quad$ reports. 2016;16(1):6.

502 3. Barrett TG, Bundey SE, Macleod AF. Neurodegeneration and diabetes: UK nationwide study of Wolfram (DIDMOAD) syndrome. Lancet. 1995;346(8988):1458-1463.

504 4. Urano F. Wolfram syndrome iPS cells: the first human cell model of endoplasmic 505 reticulum disease. Diabetes. 2014;63(3):844-846.

506 5. Fonseca SG, Ishigaki S, Oslowski CM, et al. Wolfram syndrome 1 gene negatively regulates ER stress signaling in rodent and human cells. The Journal of clinical $508 \quad$ investigation. 2010;120(3):744-755.

5096 Takei D, Ishihara H, Yamaguchi S, et al. WFS1 protein modulates the free $\mathrm{Ca}(2+)$ $510 \quad$ concentration in the endoplasmic reticulum. FEBS letters. 2006;580(24):5635-5640.

511 7. Hara T, Mahadevan J, Kanekura K, Hara M, Lu S, Urano F. Calcium Efflux From the 512 Endoplasmic Reticulum Leads to beta-Cell Death. Endocrinology. 2014;155(3):758-768.

513 8. Lu S, Kanekura K, Hara T, et al. A calcium-dependent protease as a potential therapeutic 514 target for Wolfram syndrome. Proceedings of the National Academy of Sciences of the $515 \quad$ United States of America. 2014;111(49):E5292-5301.

5169 9. Abreu D, Asada R, Revilla JMP, et al. Wolfram syndrome 1 gene regulates pathways maintaining beta-cell health and survival. Laboratory investigation; a journal of $518 \quad$ technical methods and pathology. 2020. 
medRxiv preprint doi: https://doi.org/10.1101/2020.10.07.20208694; this version posted October 12, 2020. The copyright holder for this preprint (which was not certified by peer review) is the author/funder, who has granted medRxiv a license to display the preprint in perpetuity.

It is made available under a CC-BY 4.0 International license .

Abreu \& Stone et. al.

519 10. Ellis KO, Castellion AW, Honkomp LJ, Wessels FL, Carpenter JE, Halliday RP.

520 Dantrolene, a direct acting skeletal muscle relaxant. J Pharm Sci. 1973;62(6):948-951.

521 11. Fruen BR, Mickelson JR, Louis CF. Dantrolene inhibition of sarcoplasmic reticulum

$522 \mathrm{Ca} 2+$ release by direct and specific action at skeletal muscle ryanodine receptors. $J$ Biol

$523 \quad$ Chem. 1997;272(43):26965-26971.

524 12. Paul-Pletzer K, Palnitkar SS, Jimenez LS, Morimoto H, Parness J. The skeletal muscle 525 ryanodine receptor identified as a molecular target of [3H]azidodantrolene by

526 photoaffinity labeling. Biochemistry. 2001;40(2):531-542.

527 13. Szentesi P, Collet C, Sarkozi S, et al. Effects of dantrolene on steps of excitation528 contraction coupling in mammalian skeletal muscle fibers. J Gen Physiol.

$529 \quad 2001 ; 118(4): 355-375$.

530 14. Otero-Romero S, Sastre-Garriga J, Comi G, et al. Pharmacological management of 531 spasticity in multiple sclerosis: Systematic review and consensus paper. Mult Scler. $532 \quad 2016 ; 22(11): 1386-1396$.

533 15. Sabouri M, Momeni M, Khorvash F, Rezvani M, Tabesh H. The Effect of a Single dose

534 Dantrolene in Patients with Vasospasm Following Aneurysmal Subarachnoid

535 Hemorrhage. Adv Biomed Res. 2017;6:83.

536 16. Chen X, Wu J, Lvovskaya S, Herndon E, Supnet C, Bezprozvanny I. Dantrolene is

537 neuroprotective in Huntington's disease transgenic mouse model. Mol Neurodegener.

$538 \quad 2011 ; 6: 81$.

539 17. Bezprozvanny I, Klockgether T. Therapeutic prospects for spinocerebellar ataxia type 2 $540 \quad$ and 3. Drugs Future. 2009;34(12). 
medRxiv preprint doi: https://doi.org/10.1101/2020.10.07.20208694; this version posted October 12, 2020. The copyright holder for this preprint (which was not certified by peer review) is the author/funder, who has granted medRxiv a license to display the preprint in perpetuity.

It is made available under a CC-BY 4.0 International license .

Abreu \& Stone et. al.

541 18. Liu J, Tang TS, Tu H, et al. Deranged calcium signaling and neurodegeneration in

$542 \quad$ spinocerebellar ataxia type 2. J Neurosci. 2009;29(29):9148-9162.

543 19. Shi Y, Wang Y, Wei H. Dantrolene : From Malignant Hyperthermia to Alzheimer's

$544 \quad$ Disease. CNS Neurol Disord Drug Targets. 2018.

545 20. Wang Y, Shi Y, Wei H. Calcium Dysregulation in Alzheimer's Disease: A Target for

$546 \quad$ New Drug Development. J Alzheimers Dis Parkinsonism. 2017;7(5).

547 21. Mitani AA, Haneuse S. Small Data Challenges of Studying Rare Diseases. JAMA Netw

$548 \quad$ Open. 2020;3(3):e201965.

549 22. Marshall BA, Permutt MA, Paciorkowski AR, et al. Phenotypic characteristics of early

$550 \quad$ Wolfram syndrome. Orphanet J Rare Dis. 2013;8:64.

551 23. Hershey T, Lugar HM, Shimony JS, et al. Early Brain Vulnerability in Wolfram

$552 \quad$ Syndrome. PloS one. 2012;7(7):e40604.

553 24. Marshall BA, Permutt MA, Paciorkowski AR, et al. Phenotypic characteristics of early

$554 \quad$ Wolfram syndrome. Orphanet journal of rare diseases. 2013;8(1):64.

555 25. Aguilar Bernal OR, Bender MA, Lacy ME. Efficacy of dantrolene sodium in

556 management of tetanus in children. J R Soc Med. 1986;79(5):277-281.

557 26. Tura A, Kautzky-Willer A, Pacini G. Insulinogenic indices from insulin and C-peptide:

558 comparison of beta-cell function from OGTT and IVGTT. Diabetes Res Clin Pract.

$559 \quad 2006 ; 72(3): 298-301$.

560 27. Bacha F, Gungor N, Lee S, de las Heras J, Arslanian S. Indices of insulin secretion

561 during a liquid mixed-meal test in obese youth with diabetes. J Pediatr. 2013;162(5):924-

562929. 
medRxiv preprint doi: https://doi.org/10.1101/2020.10.07.20208694; this version posted October 12, 2020. The copyright holder for this preprint (which was not certified by peer review) is the author/funder, who has granted medRxiv a license to display the preprint in perpetuity.

It is made available under a CC-BY 4.0 International license .

Abreu \& Stone et. al.

563 28. Marren SM, Hammersley S, McDonald TJ, et al. Persistent C-peptide is associated with 564 reduced hypoglycaemia but not HbA1c in adults with longstanding Type 1 diabetes: evidence for lack of intensive treatment in UK clinical practice? Diabet Med.

567

568

569

570

571

572

573

574

575

576

577

578

579

580

581

582

583

584

585 2019;36(9):1092-1099.

29. Oram RA, McDonald TJ, Shields BM, et al. Most people with long-duration type 1 diabetes in a large population-based study are insulin microsecretors. Diabetes Care. 2015;38(2):323-328.

30. Nguyen C, Foster ER, Paciorkowski AR, et al. Reliability and validity of the Wolfram Unified Rating Scale (WURS). Orphanet journal of rare diseases. 2012;7:89.

31. Stone SI, Abreu D, McGill JB, Urano F. Monogenic and syndromic diabetes due to endoplasmic reticulum stress. Journal of Diabetes and its Complications. 2020:107618.

32. Abreu D, Urano F. Current Landscape of Treatments for Wolfram Syndrome. Trends Pharmacol Sci. 2019;40(10):711-714.

33. Hoekel J, Chisholm SA, Al-Lozi A, Hershey T, Tychsen L, Washington University Wolfram Study G. Ophthalmologic correlates of disease severity in children and adolescents with Wolfram syndrome. Journal of AAPOS : the official publication of the American Association for Pediatric Ophthalmology and Strabismus / American Association for Pediatric Ophthalmology and Strabismus. 2014;18(5):461-465 e461.

34. Klein R, Moss SE, Klein BE, Gutierrez P, Mangione CM. The NEI-VFQ-25 in people with long-term type 1 diabetes mellitus: the Wisconsin Epidemiologic Study of Diabetic Retinopathy. Arch Ophthalmol. 2001;119(5):733-740.

35. Varni JW, Thompson KL, Hanson V. The Varni/Thompson Pediatric Pain Questionnaire. I. Chronic musculoskeletal pain in juvenile rheumatoid arthritis. Pain. 1987;28(1):27-38. 
medRxiv preprint doi: https://doi.org/10.1101/2020.10.07.20208694; this version posted October 12, 2020. The copyright holder for this preprint (which was not certified by peer review) is the author/funder, who has granted medRxiv a license to display the preprint in perpetuity. It is made available under a CC-BY 4.0 International license.

586 36. Ware JE, Jr. SF-36 health survey update. Spine (Phila Pa 1976). 2000;25(24):3130-3139. 587

588 
medRxiv preprint doi: https://doi.org/10.1101/2020.10.07.20208694; this version posted October 12, 2020. The copyright holder for this preprint (which was not certified by peer review) is the author/funder, who has granted medRxiv a license to display the preprint in perpetuity.

It is made available under a CC-BY 4.0 International license .

Abreu \& Stone et. al.

Figure Legends

590 Figure 1. Trial Design, Enrolment, and Retention. A) Schematic of 6-month study. Each

591 study visit is noted by a black circle. Study procedures for secondary endpoints are noted in blue.

592 The dose maximization period for dantrolene sodium is noted by the red dashed lines. B)

593 Enrollment and retention diagram for the subjects enrolled in the study. C) Histogram

594 demonstrating distribution of final tolerated dantrolene doses in pediatric subjects at the end of

595 the study. For pediatric subjects this is expressed as $\mathrm{mg} / \mathrm{kg} / \mathrm{day}$. D) Histogram demonstrating

596 distribution of final tolerated dantrolene doses in adult subjects at the end of the study. For adult

597 subjects this is expressed as mg/day. For both histograms the blue bars represent numbers of 598 subjects taking a dose, red lines represent the exact doses.

599

600 Figure 2. Secondary study endpoints. A) Hemoglobin a1c (HbA1c). B) C-peptide during a

601 mixed meal tolerance text. Light boxes represent fasting results, while dark boxes represent 30-

602 minute (stimulated) values. C) LogMAR (a measure of visual acuity). Lower score correlates to

603 more accurate vision. D) Wolfram Unified Rating Scale (WURS) Score. E) Physician rated

604 subsection of the WURS. Higher WURS scores represent more severe disease. All study subjects

605 are broken down into adult and pediatric subgroups. Responders are differentiated from non-

606 responders by having a change in $\Delta \mathrm{C}$-peptide $(\Delta \Delta \mathrm{C}$-peptide $) \geq 0.1 \mathrm{ng} / \mathrm{mL}$ over the study period

607 (see Figure 3).

608

609 Figure 3. Subgroup analysis to determine responders vs. non-responders. A) $\Delta$ C-peptide

610 was plotted between all subjects. Then the change in $\Delta \mathrm{C}$-peptide $(\Delta \Delta \mathrm{C}$-peptide) was calculated

611 for each subject over the course of the study. Subjects were stratified based on a $\Delta \Delta \mathrm{C}$-peptide < 
medRxiv preprint doi: https://doi.org/10.1101/2020.10.07.20208694; this version posted October 12, 2020. The copyright holder for this preprint (which was not certified by peer review) is the author/funder, who has granted medRxiv a license to display the preprint in perpetuity.

Abreu \& Stone et. al.

$6120.05, \geq 0.05, \geq 0.1$, and $\geq 0.2 \mathrm{ng} / \mathrm{mL}$ respectively. B) Linear regression analysis demonstrates a

613 significant positive relationship between baseline $\Delta \mathrm{C}$-peptide and $\Delta \Delta \mathrm{C}$-peptide. C) Histogram

614 demonstrating the distribution of $\Delta \Delta$ C-peptide in the study population. Solid blue line

615 demonstrates the kernel density estimate. The different cutoff values for $\Delta \Delta$ C-peptide $(0.05$,

6160.1 , and $0.2 \mathrm{ng} / \mathrm{mL}$ ) are plotted on both (C) and (D). Based on these analyses a $\Delta \Delta$ C-peptide $\geq$

$6170.1 \mathrm{ng} / \mathrm{mL}$ (depicted in red) was chosen, and these subjects are defined as 'Responders'

618 throughout the remainder of the analysis.

619

620 Table 1. Demographic and Clinical Characteristics of the Study Subjects

622 Table 2. Adverse Events During the Study

623 
Abreu \& Stone et. al.

\section{Supplementary Information}

625 Supplementary Figure 1. Grip strength of each study subject during the study. A) Right

626 hand B) Left hand. peptide. C-peptide is in $\mathrm{ng} / \mathrm{mL}$.

632 Supplementary Figure 3. Predictive value of baseline data. Histograms plotting A) Basal

633 (fasting) C-peptide, B) Stimulated (30-minute) C-peptide, C) $\Delta$ C-peptide, and D) $\Delta \Delta$ C-peptide

634 (as a positive control). Receiver-Operator-Characteristic (ROC) curves were created from these

635 data in order to plot the sensitivity vs. specificity of being a responder based on E) Basal

636 (fasting) C-peptide, F) Stimulated (30-minute) C-peptide, G) $\Delta \mathrm{C}$-peptide, and H) $\Delta \Delta \mathrm{C}$-peptide

637 (as a positive control). Area under the curve (AUC) was calculated for each ROC curve. A red

638 dashed line indicates the point with the highest sensitivity and specificity within each ROC

639 curve. This cutoff value is illustrated by a vertical line and annotated on the corresponding

640 histogram.

642 Supplementary Figure 4. Additional markers of $\beta$-cell function. A) Proinsulin collected

643 during a mixed meal tolerance text. B) Insulinogenic Index. C) Area Under the Curve (AUC) C-

644 peptide / AUC Glucose. D) C-peptide to Glucose Ratio All study subjects are broken down into

645 adult and pediatric subgroups. Light boxes represent fasting results, while dark boxes represent

646 30-minute (stimulated) values. Responders are differentiated from non-responders by having a 
Abreu \& Stone et. al.

647 change in $\Delta$ C-peptide $(\Delta \Delta$ C-peptide) $\geq 0.1 \mathrm{ng} / \mathrm{mL}$ over the course of the study (see 648 Supplementary Figure 3).

650 Supplementary Figure 5. LogMAR visual acuity plot including subject 12. Subject 12 was 651 excluded from the analysis as they are blind with a LogMar $=3$.

653 Supplementary Figure 6. Linear regression analysis. Linear regression analysis comparing

$654 \Delta \Delta$ C-peptide to (A) LogMAR visual acuity, (B) total WURS, and (C) physician rated WURS.

$655 \mathrm{R}^{2}$ and $\mathrm{p}$-values are demonstrated in the top right corner of each panel.

657 Supplementary Table S1 . Genetic and Clinical Characteristics of the Study Subjects.

659 Supplementary Table S2. Secondary Study Endpoints.

661 Supplementary Table S3. Sensitivity and Specificity

662 Table based on different cutoff values for Basal C-peptide, Stimulated C-peptide, $\Delta$ C-peptide, 663 and $\Delta \Delta \mathrm{C}$-peptide (positive control). Corresponds to Supplementary Figure 3.

667 Supplementary Table S5. Vision-related quality of life by the NEIVFQ-25.

669 Supplementary Table S6. Pediatric Quality of Life (PedsQL) questionnaire. 
medRxiv preprint doi: https://doi.org/10.1101/2020.10.07.20208694; this version posted October 12, 2020. The copyright holder for this preprint (which was not certified by peer review) is the author/funder, who has granted medRxiv a license to display the preprint in perpetuity.

It is made available under a CC-BY 4.0 International license.

671 Supplementary Table S7. Physical and mental health metrics as assessed by the SF-36v. 
Figure 1

A Visit \#

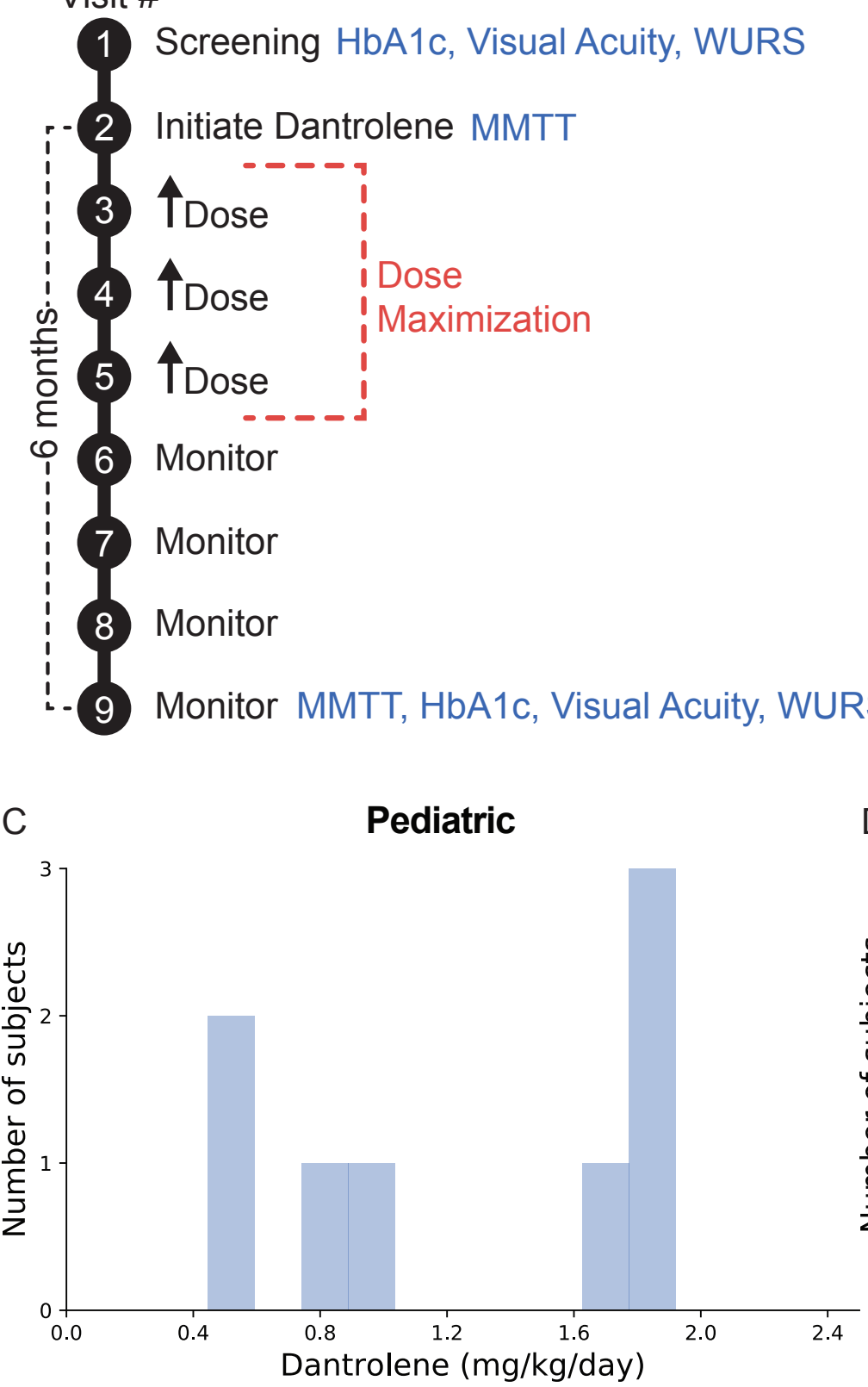

B

22 subjects with Wolfram syndrome screened

1 subject not eligible
D

19 subjects completed 6-mo dantrolene trial

\section{2 subjects excluded}

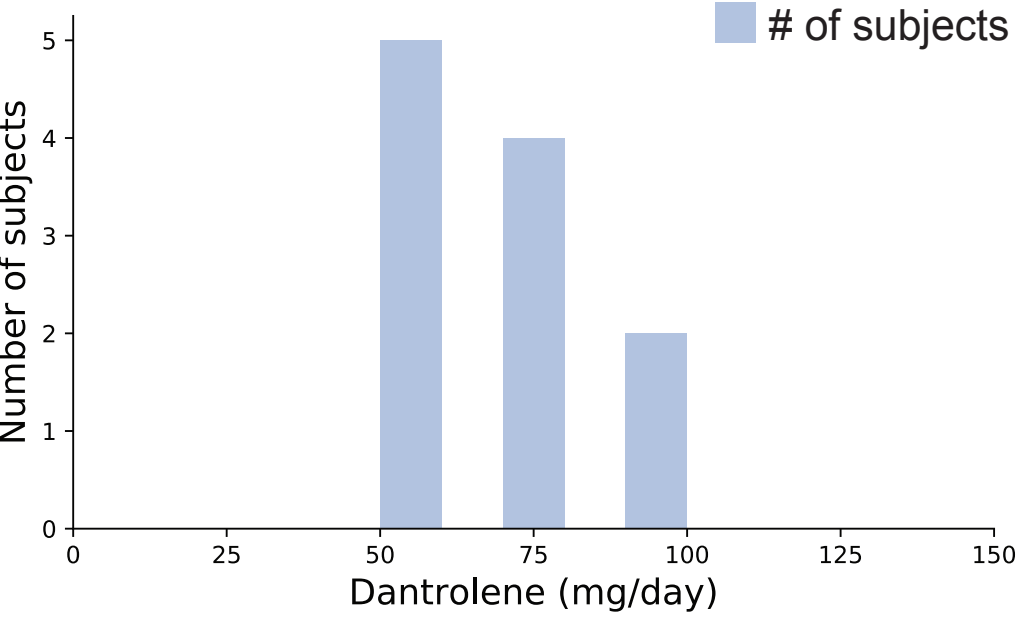


medRxiv preprint doi: https://doi.org/10.1101/2020.10.07.20208694; this version posted October 12, 2020. The copyright holder for this preprint (which was not certified by peer review) is the author/funder, who has granted medRxiv a license to display the preprint in perpetuity.

It is made available under a CC-BY 4.0 International license.

\begin{tabular}{|l|c|c|}
\hline Characteristic & Pediatric $(\mathbf{n}=\mathbf{8})$ & Adult $(\mathbf{n}=\mathbf{1 1})$ \\
\hline Median age (range) - yr & $13(6-17)$ & $23(18-32)$ \\
\hline Female sex -no. $(\%)$ & $6(75)$ & $8(73)$ \\
\hline BMI (range) $-\mathrm{kg} / \mathrm{m}^{2}$ & $20.3(15.3-29.3)$ & $27.0(17.8-48.9)$ \\
\hline Race - no (\%) & & \\
\hline Caucasian & $7(88)$ & $9(82)$ \\
\hline Hispanic or Latino & $1(13)$ & $2(18)$ \\
\hline Median age (range) - yr & & \\
\hline Diabetes mellitus & $5(3-7)$ & $6(5-14)$ \\
\hline Optic Atrophy & $7(5-14)$ & $14(6-20)$ \\
\hline Diabetes insipidus & $8(6-12)$ & $17(6-26)$ \\
\hline Hearing loss & $7(3-16)$ & $8(2-16)$ \\
\hline
\end{tabular}

Table 1. Demographic and Clinical Characteristics of the Study Subjects 


\begin{tabular}{|l|c|c|}
\hline Adverse Event: no. (\%) & Pediatric & Adult \\
\hline Dantrolene related & \multicolumn{2}{|l|}{} \\
\hline Fatigue & $3(38)$ & $5(45)$ \\
\hline Diarrhea & $2(25)$ & $3(27)$ \\
\hline Weakness & $3(38)$ & $1(9)$ \\
\hline Dizziness & $2(25)$ & $1(9)$ \\
\hline Elevated Hepatic Enzymes & $0(0)$ & $2(18)$ \\
\hline Nausea & $0(0)$ & $2(18)$ \\
\hline Gl upset & $1(13)$ & $1(9)$ \\
\hline Rash & $1(13)$ & $1(9)$ \\
\hline Wolfram related & & \\
\hline Hypoglycemia (mild) & $3(38)$ & $4(36)$ \\
\hline Headaches & $2(25)$ & $4(36)$ \\
\hline Hyponatremia & $1(13)$ & $3(27)$ \\
\hline Hyperglycemia & $2(25)$ & $1(9)$ \\
\hline Urinary tract infection & $1(13)$ & $3(27)$ \\
\hline Hyperkalemia & $1(13)$ & $0(0)$ \\
\hline Urinary retention & $1(13)$ & $0(0)$ \\
\hline Non-specific & & \\
\hline Influenza & $1(13)$ & $1(9)$ \\
\hline Rhinovirus infection & $1(13)$ & $0(0)$ \\
\hline Knee infection & $1(13)$ & $0(0)$ \\
\hline Tics & $1(13)$ & $0(0)$ \\
\hline Knee effusions & $0(0)$ & $1(9)$ \\
\hline Hit by car & $0(0)$ & $1(9)$ \\
\hline Pneumonia & $0(0)$ & $0(0)$ \\
\hline Otitis media & $0(0)$ & $0(0)$ \\
\hline
\end{tabular}

Table 2. Adverse Events During the Study 